US WURK LXVIII (2019), p.

\title{
[1452] The Mysterious Dog in Two Old Frisian Eternity Formulas
}

\author{
Rolf H. Bremmer Jr
}

Tibbe, canis familias in memoriam

2002-2019

\section{Introduction $^{1}$}

Old Frisian legal prose contains many examples of a characteristic phraseology that still appeals to readers today. Initially philologists were impressed by such passages for aesthetical reasons, a response that was developed and cherished in the wake of the Romantic Movement. On more than one occasion, the champion of Germanic studies, Jacob Grimm (17851863), intimated his admiration for the language of pristine law with its fixed sayings, alliterations and tautologies. Legal language, he claimed, distinguished itself above all by the existence of "feierlicher, wiederkehrender und sinnlich gewandter redensarten" (solemn, recurrent and sensual figures of speech). ${ }^{2}$ One particular instance of this stylistic feature to which Grimm called special attention was a phenomenon that he described as: "formeln für das unermeßliche der zeit und des raums" (formulas for the immeasurability of time and space; Grimm's emphasis). Formulas of this nature feature such notions as, in Grimm's words: "das scheinen des sonnes, fallen des regens und thaues, strömen des waßers, wehen des windes, krähen des hahns, grünen des grases" (the shining of the sun, the falling of the rain and dew, the running of water, the blowing of the wind, the crowing of the cock, the greening of the grass). ${ }^{3}$ A striking example, already adduced by Grimm, is offered by the Icelandic law code Grágás in the context of brokering a truce. Both parties swear to abide by the agreement that also includes a stiff warning for those who fail to live by it:

En sa yckaR, er gengr a gørvar sáttir eða vegr aveíttar trygðir: pa scal bann sva viða vargr, raekr oc rekiN, sem menn viðazt varga reka, cristnir menn kirkior søkia, heiðnir menn hof blóta, elldr upp breNr, iord grør,

1. I posted a draft of this paper on academia.edu and received many helpful comments. I would like to thank especially Siebren Dyk, Jarich Hoekstra, Mirjam Marti, Anne Popkema and Roland Schuhmann. Jenneka Janzen skilfully polished my English; her acumen saved me from error.

2. Jacob Grimm, Deutsche Rechtsalterthümer (Göttingen: Dieterich, 1828), 31.

3. Ibid. 37.

Us Wurk 68 (2019), s. 1-12; https://doi.org/10.21827/5c9887f4c9529 
mögr moðor callar, oc moðir mög födir. alldir ellda kyNda, scip scriðr, scildir blicia, sol scín, snæ leGr, fiðr scríðr, fura vex, valr flygr várlangan dag (stendr honom byR beiN undir báda vængi), himin huerfr, heimr er bygðr, vindr pytr, vötn til sævar falla, karlar körne sá; hann scal fiRaz kirkior oc cristna menn, Guðs hus oc guma, heim huern nema helvite.

(But he among you who breaks the settlement or fights in breach of the truce will be outlawed and driven away as far as men drive outlaws, as Christians attend church, as heathens bring sacrifices, as fire runs, as the earth grows, as a boy calls for his mother, as a mother raises her son, as men light fires, as the ship glides, as the sun shines, as the snow falls, as the Sami skis, as the pine grows, as the hawk flies the spring-long day (a direct wind stands below both wings), as the heavens turn, as the world is inhabited, as the wind whistles, as the waters fall into the sea, as men sow grain; he will be deprived of church and Christians, of the house of God and of men, of every home with the exception of hell. $)^{4}$

It should be noted that the enumer ation in the Icelandic text begins with "as far as", an indication of spatial extent. In Old Frisian on the other hand, such stock phrases expressing infinity with reference to space do not exist, as pointed out by Conrad Borchling (1872-1946). ${ }^{5}$ Instead, Frisian formulas usually begin with the phrase "as long as", a time-reference, therefore. Hence, Oebele Vries has rightly dubbed the Frisian variant "the eternity formula". ${ }^{6}$ In his book on Teutonic legal antiquities, Grimm presented three such passages, all of them from Old West Frisian sources: The Statutes of Magnus, The Oath of Truce and a charter from 1488. Rudolf Koegel (18551899), in a chapter on Old Frisian literature included in his wide-ranging history of medieval German literature, extended the list by another two. Like Grimm, he was charmed by the "hochpoetischen" (very poetic) character of such formulas. ${ }^{7}$ Borchling in turn added several further instances to the list of "herrlichen Formeln" (splendid formulas), which he deemed of

4. Vilhálmjur Finsen, Grágás: Isloendernes lovbog i fristatens tid, 2 vols (Copenhagen: Berling Bros, 1852) I, 206, quoted, with translation, from Paul S. Langeslag, Seasons in the Literature of the Medieval North (Cambridge: Brewer, 2015), 107; Grimm, Deutsche Rechtsalterthümer, 38-9.

5. Conrad Borchling, Poesie und Humor im friesischen Recht. Abhandlungen und Vorträge zur Geschichte Ostfrieslands 10 (Aurich: D. Friemann, 1908), 38.

6. Oebele Vries, "De âldfryske ivichheidsformule", Miscellanea Frisica. A New Collection of Frisian Studies, ed. Nils R. Århammar et al. (Assen: van Gorcum, 1984), 89-96.

7. Rudolf Koegel, Geschichte der deutschen Literatur bis zum Ausgang des Mittelalters, 2 vols (Strasbourg: 1894-7) I, 242-59 "Stabreimende Rechtspoesie", at 259. 
"hoher poetischer Schönheit" (high poetical beauty), ${ }^{8}$ just as Vries, in a detailed discussion of the formulas, augmented their number of attestations in his turn. ${ }^{9}$ All of these scholars are equally impressed by what they take as the 'poetical beauty' of these formulas.

Whether the anonymous creators of stock phrases expressing infinity indeed aimed for aesthetic beauty is questionable. Rather, formulas of this nature find their origin in an oral past when references to concrete situations "close to the human lifeworld", aided by mnemonic props such as alliteration and rhyme, helped people to memorize them. ${ }^{10}$ The eternity formula most often appears in Old Frisian legal documents in contexts that concern agreements concluded between two parties, most frequently establishing a truce between two feuding factions. ${ }^{11}$ There are many ways in confirming an agreement of peace or reconciliation in oral or semi-literate cultures, including shaking hands, exchanging kisses - or indeed, any ritual gesture or phraseology that would contribute to making the occasion memorable. ${ }^{12}$ In medieval Frisia a tradition had apparently arisen in which it was required that the conditions for a ceremonious suspension of hostilities between feuding parties should be finalized by reciting a solemn formula, so as to cast a spell of infinity over the truce. Typical for orality is that these formulas are structured in such a way that enables an expanding number of constituents. Eternity at its simplest is expressed by the lie of the land and the living of people, such as exemplified in the following provision:

Hweer so en man dolghet werth and hi thet calde yrsen an hem dreith, soe is sijn bote viij pund iefta xvj pund; soe is thio bote ful biseith. VVerd hem lyf iefta daed fan tha dolghe, soe scel hi and sine frijond tha

8. Borchling, Poesie und Humor, 38.

9. Vries, "De âldfryske ivichheidsformule", 90.

10. Walter J. Ong, Orality and Literacy: The Technologizing of the Word, 3rd edn, with additional chapters by John Hartley (London: Routledge, 2012), 42-3. On traces of primary orality in Old Frisian legal texts, see extensively Rolf H. Bremmer Jr, "The Orality of Old Frisian Law Texts", Directions for Old Frisian Philology, ed. Rolf H. Bremmer Jr, Stephen Laker and Oebele Vries. Amsterdamer Beiträge zur älteren Germanistik 73/Estrikken 96 (Amsterdam: Rodopi, 2014), 1-48.

11. Eternity phrases also appear in a similar context in Old Icelandic; see Elizabeth Jackson, Old Icelandic Truce Formulas (Tryggðamál) (London: Viking Society for Northern Research, 2016), who on p. 10 also briefly discusses the Old Frisian formula. I owe this reference to Oleg Gubarev.

12. See, e.g., Kiril Petkov, The Kiss of Peace: Ritual, Self and Society in the High and Late Medieval West (Leiden: Brill, 2003). 
frethethan swerra tho mannis lywe and tho landis leghere. ${ }^{13}$

(If a man is wounded and carries the cold iron within him, then his compensation is 8 pounds or 16 pounds; then the compensation is fully established. Whether life or death is his part because of the wound, he and his kinsmen must swear an oath of truce as long as people live and the land lies.)

In such formulas the actions which are referred to describe an inherent generality of nature about which there can be no mistaking: the grass grows, the wind blows, the tree blossoms, the cock crows, a child cries, the sun rises, dew falls, a pot boils, the world stands, the land lies, and new generations succeed the old. Sometimes the formula contains as many as six elements, rhyming in pairs, by which to measure the endlessness of time, as expressed in this very late example from 1590 :

sa long hondt wijcket, staek stijcket, beem bloijt, gers groijt, wolcken drijout, man efter man lijouuet. ${ }^{14}$

(as long as a dog ..., a stake sticks, a tree blossoms, grass grows, clouds drift, one generation succeeds another.)

It is the action ascribed to the dog that is the focus of my interest: what is the meaning of 'wijcket'? The twosome also occur in an earlier eternity formula, following a truce concluded in 1506:

So langh als ghers groyth, baemm bloyt, hond wyket, stoack styket, wolken by den hymel dryuwet. ${ }^{15}$

(As long as the grass grows, the tree blossoms, a dog ..., a stick sticks, clouds drift along the sky.)

13. Wybren Jan Buma, Wilhelm Ebel and Martina Tragter-Schubert, Westerlauwersches Recht I. Jus municipale Frisonum. Altfriesische Rechtsquellen 6 (Göttingen: Vandenhoeck \& Ruprecht, 1977), XXV.78. The occurrence of this formula, Vries's type III ("De âldfryske ivichheidsformule", 89), seems to have hitherto gone unnoticed, as did a similar one, this time from an Old East Frisian source, found in the proem to the Elder Rüstring Statutes: "Tha wi Frisa kersten wrdon, tha urief us thi king Kerl, sa hwersa alle liode enne kere kere, thet hi stede and stalle were bi londes legore and bi lioda libbende" (When we Frisians became Christians, Charlemagne granted us that whenever all people [that is, all adult male landowning peasants] chose a statute, that it would be valid and firm as long as land lies and people live); see Wybren Jan Buma and Wilhelm Ebel, Das Rüstringer Recht. AR 1 (Göttingen: Musterschmidt, 1963), A VIII.1.

14. Vries, "De âldfryske ivichheidsformule", 90; in context: Philippus Breuker, Frysk fan 1550 oant 1801. Oanfollingen. Estrikken 82 (Groningen: SFFYRUG, 2008), 55.

15. Pieter Sipma, Oudfriesche Oorkonden, I-III. Oudfriesche Taal en Rechtsbronnen 1-3 (The Hague: Martinus Nijhoff, 1941), III 34.11-12. 
All of these elements describe universal characteristics of the world around us: it is in the nature of grass to grow, of a tree to blossom each spring, we can see clouds drift along the sky almost every day and feel the wind blowing. Such statements are so obvious as to be almost banal. But what about the dog and the stick or stake? What is so typically universal about these two? Vries takes these two particular elements of the two formulas in which they occur to relate to an erstwhile popular game, much like playing at tipcat. Two sticks are used, a longer and a much shorter one (ca. $10 \mathrm{cms}$ ), and the challenge for the participants is to strike the shorter with the longer stick and send it flying as far as possible. In this interpretation, the staeck or stoack would refer to the longer stick, while the shorter one, called 'tipcat' in English, ${ }^{16}$ would be the hond $(t)$. Vries finds support for this interpretation in a discussion by Wybren Jan Buma of Old Frisian hund in the Emsingo Register of Compensations. This homonym hund, a hapax legomenon, seems to mean a 'club' or 'bar', with which severe injuries could be inflicted. ${ }^{17}$ Buma pointed out that in the modern Low German dialect spoken in the Dutch province of Groningen, an area that was Frisophone until the close of the Middle Ages, the tipcat is called hond. Although he could have done so, Buma did not link this lexical information with hond(t) in the eternity formula. Vries, however, does. With regard to the two verbs involved, one would be a form of wikk (strong verb class I) 'to retreat, flee', while the other would be a form of stikia 'to stick, remain' (weak verb class 2). In the game, according to Vries, the 'dog' flees, while the stick 'sticks', i.e. remains (in the hand). Vries's solution sounds attractive at first sight and was therefore adopted, albeit with some hesitance, by Hofmann and Popkema in their concise Old Frisian dictionary. ${ }^{18}$ There are three arguments, however, that on closer inspection question the validity of Vries's interpretation: the first is generic, the second grammatical, and the third semantic.

16. Oxford English Dictionary Online, s.v.

17. Wybren Jan Buma, "De hund yn 'e Iemsgoaër boeten", Us Wurk 7 (1958), 25-32. To support his interpretation, Buma erroneously adduced Oxford English Dictionary, hound n.2 'knob at the top of a mast-head', borrowed from Old Norse (húnn), which later attracted an excrescent $-d$. The same Old Norse word also entered English through Anglo-Norman French.

18. Dietrich Hofmann and Anne T. Popkema, Altfriesisches Handwörterbuch (Heidelberg: Winter, 2008), s.vv. hund 3; wīka, wiāka, wiēka; stikia. Hofmann and Popkema query the correctness of their definition, s.v. stikia. 


\section{Generic arguments}

As I have argued above, eternity formulas derive their authority from referring to conditions of a universal nature that are assumed to be both selfevident and true without further questioning: the blowing wind, the drifting clouds, the blooming tree, the crowing cock, and so on. An intricate sporting game of the kind that Vries invokes, for which we have no supportive evidence of having been played in medieval Frisia (although I would not be surprised if it had), does not fit the character of a familiar phenomenon, in my opinion. An additional argument against Vries's interpretation is that it takes both the dog and the stick as referring to one condition of eternal perpetuity - a sporting game - whereas otherwise items in the lists are mutually unrelated, stand-alone conditions. Taking the two as belonging together, therefore, runs counter to the structure of the formula. Finally, elements in the eternity formula, as has been shown, all belong to the natural world - with exception of the boiling cauldron; ${ }^{19}$ Vries's solution, on the other hand, involves a complex cultural action. All in all, this is sufficient to query the viability of taking the two elements under discussion to refer to a game.

\section{Grammatical arguments}

Grammatically, too, there are difficulties in Vries's interpretation which are silently glossed over. Both verbal forms end in -et, which is typical for 3 sg.pres.ind. of weak verb class 2 , with an infinitive ending in $-i a^{20}$ Analyzing styket as a form of OFris stikia weak verb class 2 is unproblematic. Old English has a cognate verb stician with a similar meaning 'to stick', both transitive and intransitive (cf. OHG stehhōn wv 2, 'idem'). ${ }^{21}$ The

19. In the list "alsa lange alsser dawa falt, pot walt, gers groyet, baem bloyet" (as long as dew falls, a pot boils, grass grows, a tree blossoms), Sipma, Oudfriese Oorkonden, III 20.19-20. I suppose that the boiling pot entered the formula as the result of a Pavlovian response, occasioned by the the verb-form "falt", because otherwise the cooking vessel only occurs in a popular rhyming formula to indicate someone's domicile: “deer syn pot walt en syn krawel falt" (where his pot boils and his flesh-hook falls). Instances of this formula can be found, e.g., in Pieter Gerbenzon, Codex Parisiensis. OTR 9 (The Hague: Martinus Nijhoff, 1954), VII.100-01 (“Excerpta legum”); Sipma, Oorkonden, II 29.58; Montanus Hettema, Jurisprudentia Frisica, 3 vols (Leeuwarden: Schetsberg, 1834-35), Tit. XX.2 and 6.

20. Rolf H. Bremmer Jr, An Introduction to Old Frisian: History, Grammar, Reader, Glossary (Amsterdam: John Benjamins, 2009), §154.

21. Joseph Bosworth and N. Northcote Toller, An Anglo-Saxon Dictionary (Oxford: Oxford University Press, 1898), s.v. stician. 
verb wikka 'to flee, retreat', however, is strong in the other Germanic languages (cf. OE wìcan, OS wīkan, OHG wīhhan, ON víka, etc.). Strictly speaking, therefore, the verbal form in the formula should have been wyckt or the like, without desinential $-e-$, if Vries were right. In order to save Vries's semantic interpretation, one might want to explain the form wyket as an instance of forced rhyme to go with stycket, but I think there is an easier solution. This brings us to the semantic considerations.

\section{Semantic arguments}

A complicating factor in the interpretation of hond(t) is that, theoretically speaking, it can be a reflex of both Gmc *hand- 'hand' and Gmc *hund'dog'. One of the typically Old Frisian sound changes was the rounding of $* a>o$ before nasals. However, in Old West Frisian this change was largely undone by the end of the Middle Ages. ${ }^{22}$ The rounded product lingered longest in the northeast, in the land of Oostergo, but no attestations of hond 'hand' are recorded from this region after ca. $1450 .{ }^{23}$ The attestation from 1506 is found in a charter produced in Arum (Wonseradeel in Westergo), the one from 1590 in a charter from Kiestersyl (Franekerdeel, Westergo). In other words, it can be safely excluded that hond(t) means 'hand' in the eternity formula. On the other hand, late OWFris hond < hund 'dog', displays a common change. ${ }^{24}$

So, what if we take hond(t) to refer to what seems most obvious in the context of universal experiences: a dog? And what is so characteristic of a dog? As a former dog owner I can tell from experience that, besides barking, dogs typically wag their tail in all kind of circumstances, no matter the time of day, until old age. What needs to be done, therefore, is to explore if wyket/wijcket might be a form of a verb meaning something like 'to wag, shake'. Consultation of a number of dictionaries of closely cognate languages makes clear that, theoretically speaking, such a verb expressing intense repetitive motion from side to side may indeed have existed in Old Frisian. For example, in nineteenth-century Bavarian wicken meant 'rasch

22. Bremmer, An Introduction to Old Frisian, § 208.1.

23. Arjen P. Versloot, Mechanisms of Language Change: Vowel Reduction in 15th-century West Frisian (Utrecht: Lot, 2008), 74.

24. Godard Gosses, De Friesche oorkonden uit het archief van het St. Anthony-Gasthuis te Leeuwarden. I. Een bijdrage tot de kennis der historische grammatika van het Westfriesch (Bolsward: Osinga, 1928), §§ 135-6. 
und kräftig hin und her ziehen' (to pull quickly and briskly to and fro). ${ }^{25}$ Grimm's monumental dictionary of the German language records a Middle and Early Modern High German wicken 'tanzen, springen, hüpfen' (to dance, jump, hop). ${ }^{26} \mathrm{~A}$ little closer to home, Cornelis Kiliaan in the first etymological dictionary of Dutch recorded 'wicken j. wichten. vibrare' (wicken or wichten: to vibrate), ${ }^{27}$ while the dictionary of Middle Dutch presents the following illustration, from ca. 1300: 'Doe men den keyser dede te verstane, dat hi Herasmus quite was, wicte hi thooft' (When the king was told that he had lost Herasmus, he shook his head); the Latin original has 'exagitans caput'. ${ }^{28}$ All these attestations of cognates have in common that they express a brisk and jerky motion, but there is no dog in sight. This is different for older Swedish, for in a number of early-nineteenth-century Swedish-German dictionaries vicka is glossed as 'schwanken' (to vibrate), with the collocations vicka på svansen, på stjerten 'mit dem Schwanze wedeln, schwänzeln' (to wag, shake the tail). ${ }^{29}$ Unfortunately, none of these cognate verbs, although they are weak (cf. wicte in the Middle Dutch quotation), reveal to which specific class of weak verbs they belong. This is different for the oldest cognate I have been able to find, viz. OHG wîhhôn 'sich bewegen, mit Gebärde ausdrucken' (to move, gesticulate). ${ }^{30}$ It would

25. Johannes Andreas Schmeller, Bayerisches Wörterbuch, 2 vols, revised by G. Karl Frommann (Munich, 1872-77; repr. Munich: R. Oldenbourg, 1996), s.v. wicken (p. 846).

26. Jacob and Wilhelm Grimm, Deutsches Wörterbuch-online, s.v.

27. Cornelis Kiliaan, Etymologicum Teutonicae linguae [...] (Antwerp: Plantin, 1599), S.v.

28. Eelco Verwijs and Jacob Verdam, Middelnederlandsch woordenboek, 11 vols (The Hague: Martinus Nijhoff, 1882-1941), s.v. wicken ${ }^{2}$. The quotation is from Spiegel Historiael, Tweede Partie, by Filips Utenbroeke (ca. 1300).

29. Heinrich Carl, Svenskt och Tyskt Hand-Lexikon (Örebro: N. M. Lindu, 1825); Heinrich Carl, Nytt och fullständigt Svenskt och Tyskt Lexicon med alla sådana upplysningar, som grammatikan (Stockholm: Norstedt \& Son, 1828); A. G. F. Freese, Schwedischdeutsches Wörterbuch: mit Benutzung der Arbeiten mehrerer älterer und neuerer Lexicographen [...] (Stralsund: Löffler, 1842), s.v.; see also Elof Hellquist, Svensk etymologisk ordbok (Lund: Gleerup, 1922), s.v. vicka, for older attestations of the verb.

30. Rudolf Schützeichel, Althochdeutsches Wörterbuch, 7th edn (Berlin: de Gruyter, 2012), s.v. wîhhôn; Jochen Splett, Althochdeutsches Wörterbuch: Analyse der Wortfamilienstrukturen des Althochdeutschen [...] (Berlin: de Gruyter, 1993), 1121. Both dictionaries posit a long stem vowel; cf. Elmar Seebold, Vergleichendes und etymologisches Wörterbuch der germanischen starken Verben (The Hague: Mouton, 1970), s.v. *weik-a, where he postulates a weak verb, class 2 , from Gmc *wīkōja)- 'schnell bewegen'. 
seem to me then, based on the evidence presented by various cognates, that wycket is a form of wikia/wikkia 'to wag the tail'. It might be objected, though, that verbs meaning 'to wag' usually have the object expressed, viz. the tail. This objection can be neutralized by pointing out that in Dutch, for example, kwispelen 'to wag the tail' can be used with and without the object, probably because it is clear what the dog is doing. The same might have been the case in late Old Frisian. Alternatively, the absence of an object might be accounted for as the result of forced rhyme.

Now that the problem of the dog and its activity has been settled, Vries's solution for stoack styket/staec stijcket 'the stick remains in the hand (with reference to a certain game)' calls for revision too. It should first be noted that the nouns in this collocation are not the same. One formula element has staeck, which in classical Old Frisian would probably have been staka m., possibly stake f., 'stake', in view of OE staca m. 'stake', MDu/MLG stake m.f., which form was borrowed as German Stake. ${ }^{31}$ However, Hofmann and Popkema do not give such a lemma in their Old Frisian dictionary. Although von Richthofen did, later scholars proved him wrong for the specific passage in which he assumed it occurred. ${ }^{32}$ Nevertheless, it would seem the word existed after all in Frisian, but what did it mean?

A stake, according to the Middle Low German dictionary, is a 'lange Stange, bes. die zugespitzt ist, was aber nicht nothwendig im Begriffe des Wortes liegt' (long rod, esp. a pointed one, but this aspect is not necessarily contained in the word itself). ${ }^{33}$ The Oxford English Dictionary Online is more extensive in its definition of 'stake', but concurs with the definition given for Middle Low German in taking a stake to be pointed: 'stout stick or post, usually of wood, with a pointed end for driving into the ground; used e.g. to mark a boundary or site, to support a plant, to secure an animal, to form one of the component parts of a fence, hedge, or the like'. The Middle Dutch dictionary also comments on dimension for stake: 'Stok van verschillende lengten en dikten en voor verschillende doeleinden gebruikt, staak, stang; soms, doch niet uitsluitend met eene scherpe punt, spitse stang' (Stick

31. Elmar Seebold, Kluge. Etymologisches Wörterbuch, 23rd edn (Berlin: de Gruyter, 1995), s.v.

32. Karl von Richthofen, Altfriesisches Wörterbuch (Göttingen: Nicolai, 1840; repr. Aalen: Scientia, 1960), s.v. stake; cf. Wybren Jan Buma, Die Brokmer Rechtshandschriften. Oudfriese Taal en Rechtsbronnen 5 (The Hague: Martinus Nijhoff, 1949), 262, s.v. stak(k), with literature; Hofmann and Popkema, Altfriesisches Handwörterbuch, s.v. 'stak 'Umhang' (mantle).

33. Karl Schiller and August Lüben, Mittelniederdeutsches Wörterbuch, 6 vols (Bremen: Kühtmann, 1875-1881), s.v. 
of different lengths and sizes and used for various purposes, stake, rod; sometimes, but not exclusively, with a sharp point, a pointed rod), ${ }^{34}$ All three definitions comment on the stake often being pointed, a feature that facilitates driving it into the ground or anywhere else (a wall, someone's behind), or to put something on to (a head, e.g.). There is no reason to doubt that the word had a similar range of meanings in Old Frisian too.

As for the verb, it should be noted that in Old English, stician can both be transitive and intransitive. When intransitive, it signifies 'to stick, remain fixed'. ${ }^{35}$ The same holds for OHG stehhōn ${ }^{36}$ both the English and German verb belong to weak verbs class 2. In Modern Frisian, the verb stykje still exists, is intransitive and also means 'to remain fixed'. ${ }^{37}$

Furthermore, and not surprisingly so perhaps, the noun and verb are often found together. The $O E D$ s.v. stick gives quite a few illustrations in which stake and to stick (both transitive and intransitive) come in one breath; the Middle Low German dictionary gives one. ${ }^{38}$ In Middle Dutch, likewise, the noun and verb went together: 'Die rustet neuen sijn huys: ende die een staec steect in sine want, Hi sal sijn huys setten tot sijnre hant (Ecclesiasticus 14:27)' (He that lodgeth near her house, and fastening a pin in her walls shall set up his tent nigh unto her; Douay-Rheims). In short, it is in the nature of a stake to stick, whether on(to) or in(to). Can the same be said of a stoack?

The stoack, or in classical Old Frisian stok, is glossed as 'Stock, Stab' (stick, staff) by Hofmann and Popkema. ${ }^{39}$ As a second meaning they add 'Stock (zweiteiliger Block, in den die Füße Gefangener geschlossen werden)' (two-part board in which a prisoner's feet are locked), in other words 'the stocks'. It is needless to say that this latter meaning is hardly

34. Verwijs en Verdam, Middelnederlandsch woordenboek, s.v.

35. Bosworth and Toller, An Anglo-Saxon Dictionary, s.v. stician II (intrans.).

36. See Seebold, Kluge, s.v. stecken; cf. Deutsches Wörterbuch, s.v. stecken 2: "eine dauer- und zustandsbildung" (a duration and situation formation). In MDu, steken (< *stikian-) Wv. 2 and steken (<*stekan-) sv. V phonologically collapsed and continued as a strong verb.

37. Wurdboek fan de Fryske taal/Woordenboek der Friese taal, ed. K. F. van der Veen et al. 25 vols (Leeuwarden: Fryske Akademy, 1984-2004), s.v. stykje I.2.

38. E.g., "he raane to a stake and hym Stickyd throw the body" (1500), "where the surveyor stuck a stake" (1827), 'The front of the rampier thus stucke with stakes' (1600). In English, too, the descendants of stecan V and stician 2 interfered. Schiller and Lüben, Mittelniederdeutsches Wörterbuch, s.v. sticken: "were dat jeniche man staken stickede unrechte .." (if any man sticks up stakes unlawfully ...).

39. The <oa>-spelling might indicate the vowel had been lengthened, cf. ModWFris stôk [sto:k]. 
appropriate in an eternity formula, so I shall ignore it. Since Hofmann and Popkema's entry is a gloss rather than a definition it might be helpful to consult a few relevant dictionaries. The Early Middle Dutch dictionary, taking stock of the language between 1200 and 1300, defines stoc as (1) 'lang en smal stuk hout' (a long and elongated piece of wood), with three subdivisions: '(herders-)staf' (staff, shepherd's crook); 'knuppel' (club, truncheon); 'draagstok' ([carrying] pole); (2) 'kort en dik stuk hout' (short and thick piece of wood) - quite the reverse of (1) - with again three subdivisions: 'boomstronk' (trunk of a tree); 'blok' (stocks); 'offerblok' (poor box, collection box [in church]). ${ }^{40}$ The Middle Dutch dictionary lists no fewer than nineteen different meanings or shades of meaning for stoc, too many to record here, but the most relevant seem to me: (1) 'De stam of staak van boom en plant; zoowel de geheele stam als de afgehouwen tronk (trunk or stem of tree and plant (both the full trunk and the stump); (2) 'boomtak, rijs, twijg' (tree-branch, wicker, twig); (4) 'staak, lange, dunne paal' (stake, long, slender pole); (5) 'steel (van bloem; ook van gereedschap)' (flower-stem; also haft/handle [of a tool]); (6) 'spaak van een wiel' (spoke of a wheel); (8) 'stok; ook knuppel' (stick; also club). ${ }^{41}$ Schiller and Lüben's Middle Low German dictionary, though far less extensive than its Middle Dutch counterpart, concurs to a great extent. If a choice must be made, meaning (4), 'stake', seems most likely to me, especially since it agrees in meaning with staec. If this choice is right, the possibility should not be excluded that stoack is a scribal error for staack. In either case, however, whether staeck or stoack, the meaning of the collocation can be best represented as '(as long as) a stake sticks', that is, as long as the stake fulfils the function for which it is made: sticking in the ground, whether as a signpost or a boundary marker, or, even in a fairway to mark a navigable course. Whether 'stake' or 'stick', the fact that both the nouns and verb have almost similar alliterating forms /stVk-/ may have been an additional factor in joining them, for the collocation follows the pattern of a figura etymologica. This stylistic combination of a noun and a verb that are etymologically related (e.g.: to sing a song) was a frequent feature of Old Frisian legal prose. ${ }^{42}$ Although modern etymologists do not favour such a

40. Willy Pijnenburg et al., Vroegmiddelnederlands woordenboek [...] (Leiden/Groningen: Instituut voor Nederlandse Lexicologie/Gopher, 2001), s.v.

41. Verwijs en Verdam, Middelnederlandsch woordenboek, s.v.

42. Rolf H. Bremmer Jr, "Dealing Dooms: Alliteration in the Old Frisian Laws", Alliteration in Culture, ed. Jonathan Roper (Basingstoke: Palgrave MacMillan, 2011), 74-92, at $85-6$. 
relation between the nouns 'stake' or 'stick' and the verb 'to stick', it seems to me that to a medieval composer the relation was quite obvious.

\section{Conclusion}

Summing up, the collocations hond wiket and stak stiket (in normalized late Old Frisian spelling) do not refer to technical terms in a sporting game as posited by Vries, but must be taken at a more literal level of meaning: 'a dog wags its tail' and 'a stake sticks'. Such an interpretation much better agrees with the nature of the other characteristic qualities of other natural phenomena enumerated in Old Frisian eternity formulas. The implication of this alternative interpretation is that the relevant entries in Hofmann and Popkema's Altfriesisches Handwörterbuch should be rid of references to a sporting game, while future dictionaries of Old Frisian should contain the entries wikia/wikkia 'to wag the tail (of a dog)', stāk (or staka/-e in classical Old Frisian) 'stake', stok 'stake', stikia wv. 2 'to stick (up, into); to remain (stuck)'.

Universiteit Leiden/Fryske Akademy Leeuwarden

r.h.bremmer@hum.leidenuniv.nl 